\title{
Analysis of Roof Failure at the Intersections on a Coal Mining
}

\author{
Andre C. Zingano, Marcelo Andrade \\ Universidade Federal do Rio Grande do Sul, Porto Alegre, Brazil \\ Email: andrezin@ufrgs.br
}

How to cite this paper: Zingano, A.C. and Andrade, M. (2021) Analysis of Roof Failure at the Intersections on a Coal Mining. Journal of Minerals and Materials Characterization and Engineering, 9, 499-511. https://doi.org/10.4236/jmmce.2021.95033

Received: July 28, 2021

Accepted: September 6, 2021

Published: September 9, 2021

Copyright (c) 2021 by author(s) and Scientific Research Publishing Inc. This work is licensed under the Creative Commons Attribution International License (CC BY 4.0).

http://creativecommons.org/licenses/by/4.0/

\section{(c) (i) Open Access}

\begin{abstract}
The objective of this paper is to understand the behavior of the roof and the cause of roof failure of a coal mining. Eleven roof falls occurred in the mine section in sequence. All the roof falls were surveyed, and the geological features were determined which include rock type, mechanical properties, and thickness. The immediate roof thickness was interpolated to determine the cause of the roof failures which was the inappropriate roof support where the immediate roof is thicker. The average thickness of the immediate roof was determined by the drilling log in $1.2 \mathrm{~m}$ ( $3.9 \mathrm{ft}$.). The roof support was design based on the average thickness, and the bolt length is $1.5 \mathrm{~m}$ (4.9 ft.) in suspension. The challenge was to estimate where the immediate roof gets thicker and to design the support considered to maintain the regular bolt length. This is because the cost and productivity of support operation could increase if the bolt length changes as the roof thickness changes. The idea was to adjust the support for beam building with a fully grouted bolt and rearrange the bolt geometry to keep the roof stable. It means, with the same bolt length the type of roof support would change from suspension to beam building depending on when the roof gets thicker. Two empirical approaches were considered to design the roof support: 1) CMRR and 2) RMR. The entry width is $5 \mathrm{~m}$ and the roof support was designed with four bolts per row. Where the roof support must change to beam building, the number of bolts per row changes to five or six. The results of the design and application on underground showed that the approach keeps stable.
\end{abstract}

\section{Keywords}

Roof Failure, Coal Mining

\section{Introduction}

Most coal mines in the southern states of Brazil are room-and-pillar underground 
mining. The excavation method is still part of conventional mining and most are continuous miner methods. The roof support is with a rock bolt 1.5 to $2.2 \mathrm{~m}$ long, and $19 \mathrm{~mm}$ diameter. Most of the bolts are fully grouted bolts, even when the only suspension is needed. Reinforcement with steel straps and mesh is required depending on the quality of the roof. The mining section usually is 5 to 7 entries, with 5 to $6 \mathrm{~m}$ wide.

In a specific section, there was a sequence of roof falls occurred 2 - 3 weeks after mined. Those roof failures happen most at intersections and entries. Only one roof fall happens at the crosscut (Figure 1). In order to understand the features of the roof, which would the cause of the roof failure, inspections were carried out on the fall locations, and all the roof characterization in terms of layer thickness, and geomechanical features were considered. Also, the time-lapse between bolting and failure is an issue because the roof failed a long time after bolting.

One characteristic of these falls was the roof bolts were down together with the rock. It means that there was no suspension support. The thickness of the immediate roof (siltstone) was higher than the average of $1.1 \mathrm{~m}$ (Figure 2).

The objective of this paper is to understand the behavior of the roof, and the cause of eleven roof failures in a row in a coal mining section. To get this objective, a sequence of in situ surveys of all roof falls, determine the rock mass quality for each roof layer, and its thickness, as well as the geometry of the entries and intersections.

\section{Roof Support Specifications}

In this case study, the roof support is a conventional suspension method, because the average roof geology (Figure 3 ) is a weak siltstone layer with 0.7 to 1.1 $\mathrm{m}$ thick, above a strong sandstone layer with 1.5 to $1.7 \mathrm{~m}$ thick, and above another siltstone layer with more than $1.0 \mathrm{~m}$ thick.

The roof support specifications are in Table 1. The roof bolt is anchored in the sandstone layer, assuming an anchor length at least $0.3 \mathrm{~m}$. The resin anchored length of the bolt is about $0.75 \mathrm{~m}$, half of bolt length, perhaps the objective is to suspend the siltstone layer as immediate roof. The bolt spacing is $1 \mathrm{~m}$, and 5 bolts per line. The geometry layout for the roof support is found at Figure 4.

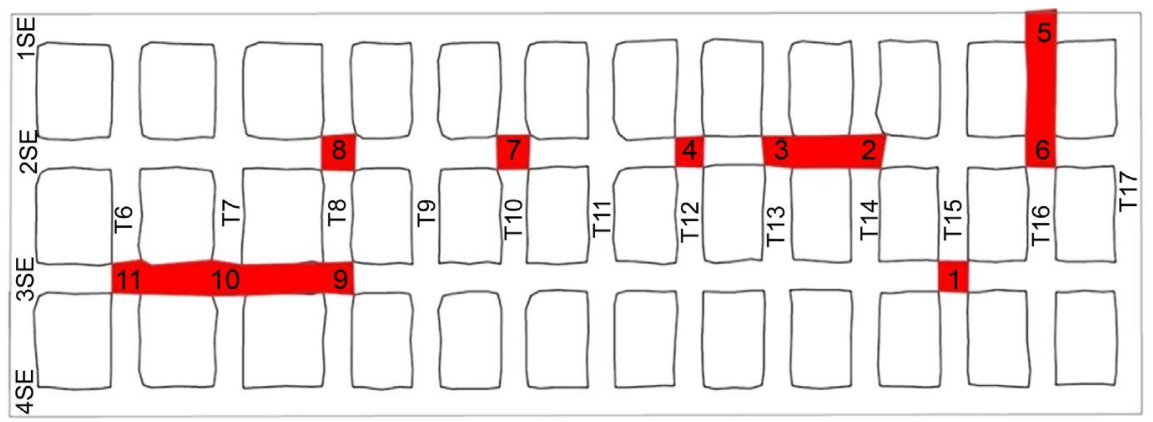

Figure 1. Location of the 11 roof falls in the mining section. 

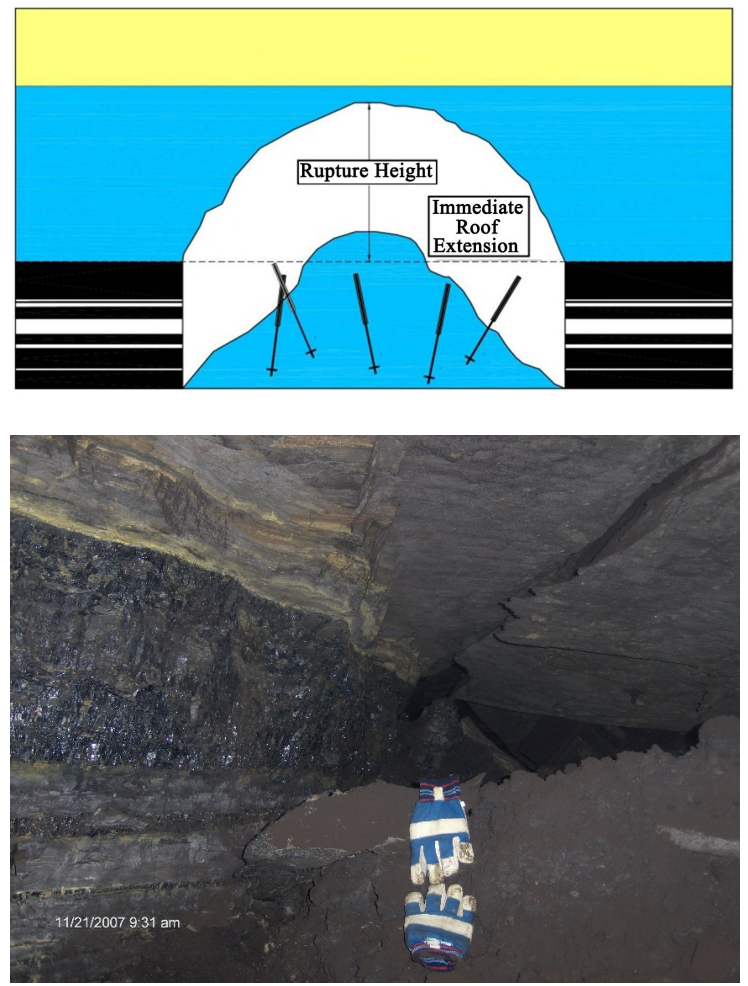

Figure 2. Roof failure due to the immediate roof thickening

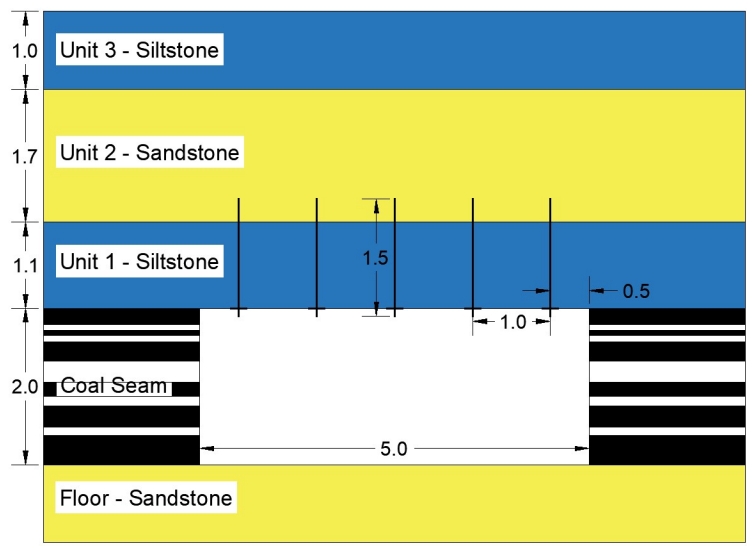

Figure 3. Roof geology sequence (ref. author).

Table 1. Pattern roof support specifications.

Bolt Spacing: $1 \mathrm{~m}$

Bolt Number: in galleries (5); in the diagonal direction (7)

Bolt Length: $1.50 \mathrm{~m}$; active length: $1.40 \mathrm{~m}$

Point-anchor/resin-assisted; length of resin column: $0.75 \mathrm{~m}$

Bolt Diameter (ø): $16 \mathrm{~mm}$

Bolt Capacity: $10,000 \mathrm{~kg}$

Pre-tension: $12 \mathrm{Kgf} / \mathrm{m}$

Grade of Steel: $540 \mathrm{MPa}$ 

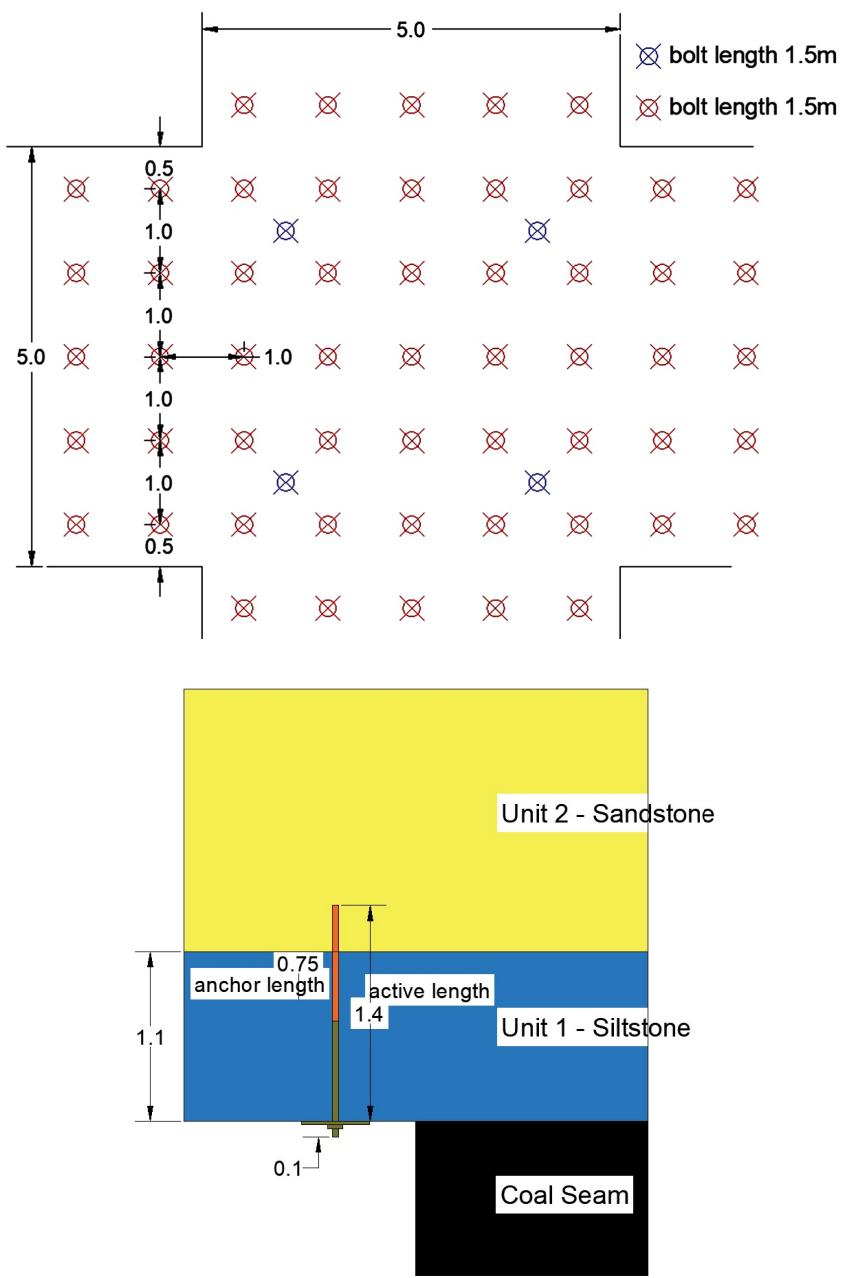

Figure 4. Geometry layout of roof support, and bolted layers.

Based on [1], the standard designed support system was developed from core logging geological/geotechnical description, geomechanical classification (RMRRock Mass Rating), and empirical equations, which aggregate this quality index of the rock mass to the roof support design.

The reinforcement mechanism proposed is the suspension of the immediate roof to create a beam of the siltstone immediate roof pushing the siltstone layer against the sandstone layer. In this case, the beam build is achieved with the pre-tensioned and anchored risers with resin, in a minimum interval of $0.30 \mathrm{~m}$ into a more competent geotechnical unit (sandstone).

\section{Diagnosis of the Roof Falls}

Each roof fall (Figure 1) was visited and surveyed considering the following parameters: 1) height of the fall roof; 2) rock type and thickness; 3) diagonal dimension for intersection; 4) presence of faults; 5) water flow or moisture.

In terms of presence of water (or moisture) and faults, there was no observation of these two features. It means there was no discontinuity or humid that could change the strength of the siltstone layer or cut the roof beam. 
The fall roof height is important, because it indicates the thickness of the immediate roof and the quality of the siltstone layer, considering the approach of [2]. Table 2 shows the roof failure height for all roof falls. The average failure height is $2.7 \mathrm{~m}$, and the maximum height is $3.1 \mathrm{~m}$. also, it's important to say that only the siltstone layer was gotten by the failure. Therefore, the first cause of the roof failure is the increment of the siltstone thickness, from $1.1 \mathrm{~m}$ to $3.1 \mathrm{~m}$ (maximum measure). It means that the roof support turned layer reinforcement, no suspension anymore.

The intersections (Figure 5) were measured the diagonals, and the average is about $8.49 \mathrm{~m}$. The expected diagonal of the intersection is $7.1 \mathrm{~m}$ since the entry width is $5 \mathrm{~m}$. In fact, the corner of the pillar will not be perfect, because the stress relieves and effect of the blasting. Therefore, it could say that change of intersection wide most of the time will be larger than the expected. In this case, the average diagonal intersection is $1.4 \mathrm{~m}$ larger than the planned. Table 3 shows the average intersection diagonal dimension for each roof fall.

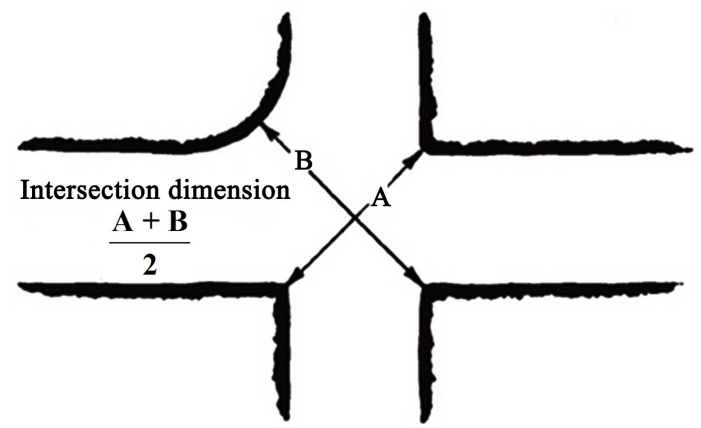

Figure 5. Measure procedure for intersection diagonal.

Table 2. Roof failure height for all roof falls.

\begin{tabular}{cc}
\hline & Rupture Height \\
\hline Failure \# & Height $(\mathrm{m})$ \\
\hline 1 & 2.35 \\
3 & 2.55 \\
4 & 2.98 \\
5 & 3.10 \\
6 & 2.47 \\
7 & 2.59 \\
8 & 2.48 \\
9 & 2.67 \\
10 & 2.72 \\
11 & 2.79 \\
Average & 3.10 \\
Maximum & 2.70 \\
Minimum & 3.10 \\
& 2.35
\end{tabular}


Table 3. Average diagonal dimension for the roof falls.

\begin{tabular}{cc}
\hline Intersection & Dimension $(\mathrm{m})$ \\
\hline 1 & 8.18 \\
2 & 8.97 \\
4 & 8.14 \\
5 & 7.89 \\
6 & 8.50 \\
7 & 8.20 \\
8 & 8.95 \\
9 & 9.31 \\
10 & 8.22 \\
11 & 8.69 \\
Average & 8.34 \\
Maximum & 8.49 \\
Minimum & 9.31 \\
\hline
\end{tabular}

One borehole drilling was done at the area of the case study section to check the thickness of the roof layers, and to define the geomechanical behavior of each layer. The borehole drilling determined that the thickness of the siltstone increased to $2.6 \mathrm{~m}$, and sandstone layer is $1.97 \mathrm{~m}$. The average roof failure height is $2.7 \mathrm{~m}$, very similar to the borehole measure. Since the bolt length is only 1.5 $\mathrm{m}$, there is no suspension support, because the bolt did not reach the sandstone layer. Therefore, the roof bolts are working as reinforcement rock mass by in layer beam building, although the anchored length for the bolt is half of the bolt length. Therefore, the beam built for the bolts is only $0.75 \mathrm{~m}$. This beam built is not enough to support the rock mass above it. Figure 6 shows that the anchor of the roof bolts is in the siltstone layer.

\section{Geomechanical Classification}

The survey of the roof falls, and the borehole indicated that the thickness of siltstone layer increased to $2.6-2.7 \mathrm{~m}$, in average. Since the roof support worked as beam built in the siltstone layer, and the beam thickness was not enough to support the roof load at the intersections, why the roof failure took long time to happen? And for the next mining section, what should the bolt length to build an appropriate beam to support the roof load? For sure, the bolt must be fully grouted bolt.

Figure 7 and Table 4 show the results of the geological sequence of the roof, where the all the roof failures occurred. The RMR—Rock Mass Rating [3] was considered to determine the rock quality for the immediate roof and main roof (sandstone) from the geomechanical description of the drill cores of the 


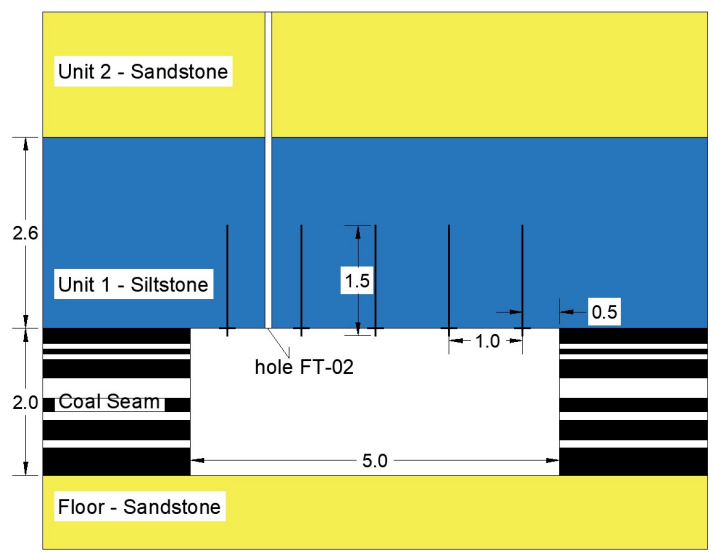

Figure 6. Geology sequence for the roof at the section in this case study, from drilling hole survey.

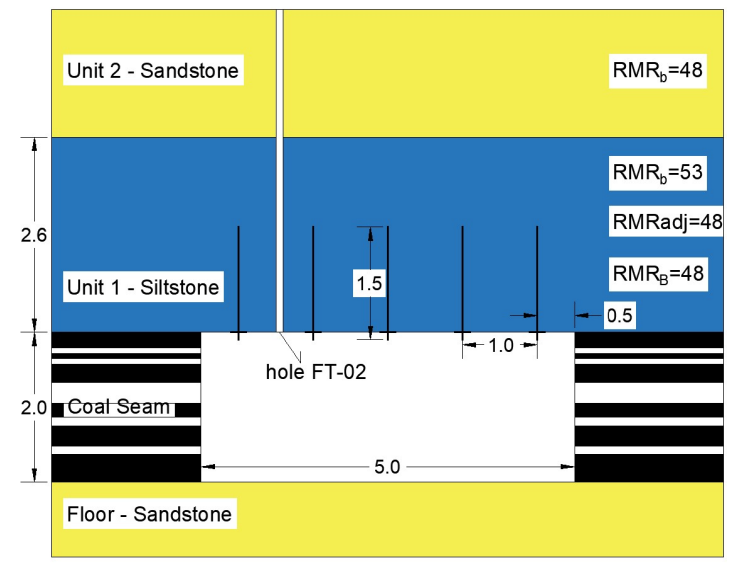

obs: $R_{M M R_{b}}$ is RMR basic

$\mathrm{RMR}_{\text {}}$ is RMR adjusted for discontinuity orientation $\mathrm{RMR}_{\mathrm{B}}$ is considering blast damage

Figure 7. Geomechanical characterization of the roof layers from drill core description.

Table 4. Geotechnical characteristics for the roof layers according to the RMR.

\begin{tabular}{|c|c|c|c|c|}
\hline \multirow{2}{*}{ Parameter } & \multicolumn{2}{|c|}{ Unit 1-Siltstone (roof) } & \multicolumn{2}{|c|}{ Unit 2-Sandstone } \\
\hline & Feature & Rating & Feature & Rating \\
\hline UCS & $43 \mathrm{MPa}$ & 5.3 & $92 \mathrm{MPa}$ & 9.0 \\
\hline Spacing of Discontinuities & $9.20 \mathrm{~cm}$ & 6.5 & $8.5 \mathrm{~cm}$ & 6.2 \\
\hline RQD & $61.35 \%$ & 12.2 & $43.15 \%$ & 8.6 \\
\hline Condition of Discontinuities & $\begin{array}{c}\text { smooth surface, } \\
\text { no infilling, } \\
\text { unweathered, } \\
\text { separation }>5 \mathrm{~mm}\end{array}$ & 14.0 & $\begin{array}{l}\text { smooth surface, } \\
\text { hard filling }>5 \mathrm{~mm}\end{array}$ & 9.0 \\
\hline Groundwater Conditions & dry & 15.0 & dry & 15.0 \\
\hline RMR basic $\left(\mathrm{RMR}_{\mathrm{b}}\right)$ & - & 53 & - & 48 \\
\hline $\begin{array}{c}\text { Adjustment for } \\
\text { Discontinuity Orientations }\end{array}$ & fair orientation & -5 & - & - \\
\hline RMR adjusted ( RMR $_{\text {adjusted }}$ ) & - & 48 & - & - \\
\hline $\begin{array}{l}\text { RMR with blaster damage } \\
\text { Adjustment }\left(\mathrm{RMR}_{\mathrm{B})}\right.\end{array}$ & moderate damage $\left({ }^{\star} 0.9\right)$ & 43 & - & - \\
\hline
\end{tabular}


borehole drilling. In order to quantify the effect of blasting on the quality of the immediate roof, the final index of the siltstone layer (RMRB $=43$ ) was adjusted by an index (0.9) suggested by [4].

The numbers in Figure 7 should be changed, change $1.97 \mathrm{~m}$ to $1.97 \mathrm{~m}, 2.60 \mathrm{~m}$ to $2.60 \mathrm{~m}$. The author messed up comma and dot.

Thus, according to the criteria considered in the RMR geomechanical classification, for the definition of weights attributed to each of the parameters and adjustments, the $\mathrm{RMR}_{\mathrm{B}}$ and $\mathrm{RMR}_{\mathrm{b}}$ index obtained from the geomechanical characterization from the drill hole for the two roof layers present values of 43 and 48 (Table 4) that means they are poor rock mass layers (Class III).

The height of roof rock that loads the support is defined by equation [2]. Based on this equation, the height $\left(h_{t}\right)$ for siltstone layer is $4.8 \mathrm{~m}$ for average diagonal of the intersection.

$$
h_{t}=\frac{100-\mathrm{RMR}}{100} B
$$

Reference [2] determined the back analysis of RMR index $\left(\mathrm{RMR}_{\text {retro }}\right)$ as a ratio between the depth of the failure cavity (Table 1 ) and the geometry dimensions of the excavations (Table 2), as shown in Equation (2). Where: $h_{t}^{\prime}$-represents measured failure height; $B^{\prime}-$ represents the measured in of the intersections.

$$
\mathrm{RMR}_{\text {retro }}=100\left(1-\frac{h_{t}^{\prime}}{B^{\prime}}\right)
$$

Therefore, the application of Equation (2) directed to the intersection dimensions of the roof failures cases (Table 2), allowed to obtain the RMR indexes for the average, and maximum/minimum dimensions of the diagonal intersections, referred to in the present study as $\mathrm{RMR}_{\text {retro }}$ (Table 5).

The difference between RMR from drillhole and RMR from back analysis can be explained by the fact that the top of the roof failure is the bottom of the sandstone layer. It means that the siltstone layer thickness is smaller than the $h_{t}$ estimated using Unal's equation.

CMRR is a geomechanical classification system, exclusively for the evaluation of the quality of the roof rock layers for underground coal mines [5]. The sequence of rock units or description of drill cores can used to define the CMRR [6].

Figure 8 and Table 6 are showing the results of the two main geotechnical

Table 5. RMR estimated from roof failures cases and based on Equation (1).

\begin{tabular}{ccc}
\hline $\begin{array}{c}\text { Typical dimension in entries intersections } \\
\left(\mathrm{B}^{\prime}\right)\end{array}$ & $\begin{array}{c}\text { Rupture Height } \\
\left(\mathrm{h}_{\mathrm{t}}\right)\end{array}$ & $\begin{array}{c}\text { RMR }_{\text {retro }} \\
* 7.89 \mathrm{~m}\end{array}$ \\
$\begin{array}{c}* * * 9.31 \mathrm{~m} \\
* * 8.49 \mathrm{~m}\end{array}$ & 2.35 & 67 \\
\hline
\end{tabular}

${ }^{*}$ minimum, ${ }^{* *}$ maximum and ${ }^{* *}$ average. 


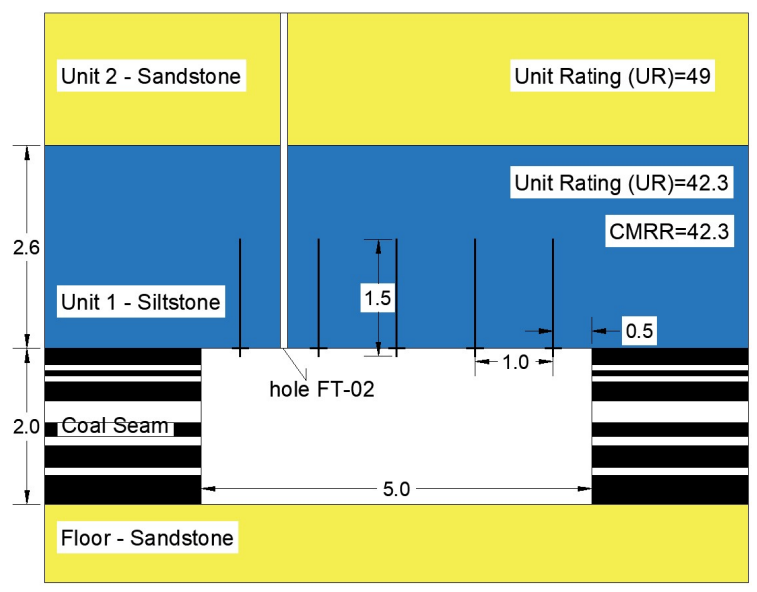

Figure 8. Geological and geotechnical profile defined for the roof by CMRR approach.

Table 6. CMRR classification for the layers that will form the roof.

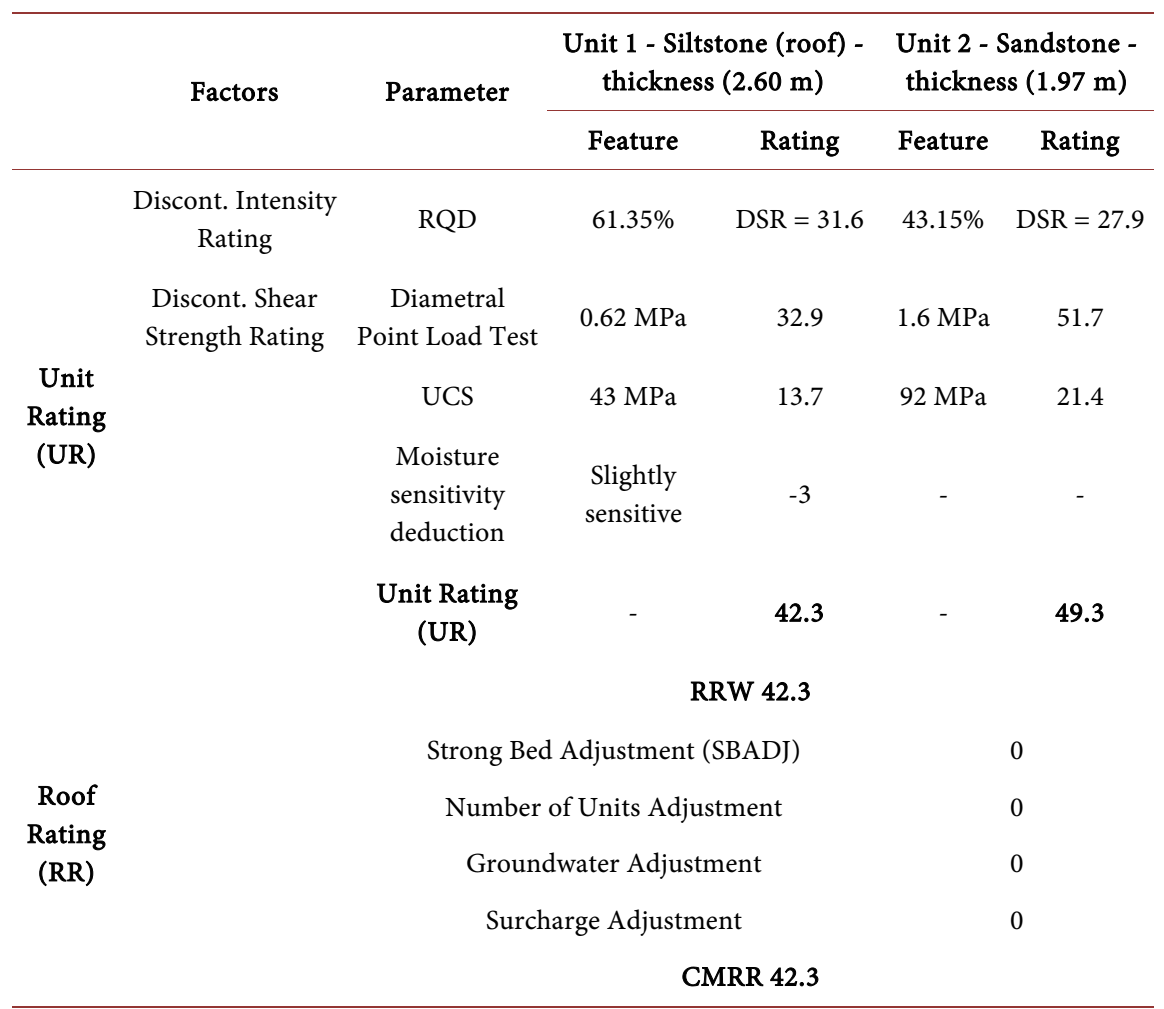

units which are individually monitored for thickness and quality of the roof layers, as well as the CMRR index for the bolted region.

Therefore, according to the criteria established by [6] in the geomechanical qualification of the roof from drill cores, the CMRR index is 42.3 (Table 8). This is classified as a poor or weak roof according to the condition although it is situated in the range of $0-45$.

\section{Roof Support Design}

Determining the characteristics of the roof support system at intersections repre- 
sents a major challenge in underground coal mining. This fact is due to difficulties encountered in controlling the size of intersections (diagonals) due to lack of care by mine operators or due to the concentration of stress at the corners of the pillars [4]. Considering the suspension reinforcement mechanism, [5] highlights its inapplicability directed to cases where the incompetent unit that has thickness more than one meter.

The survey described above showed that the average roof layer thickness at the mining section in this case study is higher (Table 2) than the assumed average that was used for roof support design $(1.1 \mathrm{~m})$. Therefore, suspension system could not be applied at this case.

The roof support design for this case study must consider the reinforcement system of the immediate roof using fully grouted roof bolt. The RMR approach by [6] and Bieniawski [3] [7] [8] was applied to design the roof support. Therefore, for this case study, RMR method $\left(\mathrm{RMR}_{\mathrm{B}}=43\right.$ and $\left.\mathrm{RMR}_{\text {retro }}=68\right)$ was considered to roof support design. Table 7 and Table 8 present the bolt design for entries and intersections respectively. The bolt diameter and spacing considered a Safety Factor 1.7. The bolt diameter is $19 \mathrm{~mm}$ (3/4 in.), and number of bolts per line and spacing between lines depends on the quality of the immediate roof.

The roof support design considering the CMRR approach, the value of CMRR 42.3 was considered, based on the geomechanical description.

The recommended support intensity measures-PRSUPG [9] should be achieved by the adopted bolt system. The mesh and capacity of the bolts are also variables to be considered for a support design. The Equation (3) is defined by the ARBS method.

$$
\operatorname{PRSUP}=\left(L_{B} N_{B} C\right) /\left(S_{B} W_{e}\right)
$$

where:

PRSUP = intensity or load supported by the bolt pattern $(\mathrm{t} / \mathrm{m})$;

$L_{B}=$ bolt length (m);

$N_{B}=$ Number of bolts per line;

$C=$ Bolt capacity (t);

$S_{B}=$ Spacing between bolt lines (m);

$W_{e}=$ Entry width $(\mathrm{m})$.

Table 7. Roof support design for entries, considering bolt diameter $16 \mathrm{~mm}(5 / 8 ")$.

\begin{tabular}{cccccc}
\hline RMR scenario & Rating & Entry width & Bolt length & $\begin{array}{c}\text { Bolt spacing } \\
(\mathrm{SF}=1.7)\end{array}$ & $\begin{array}{c}\text { Numbers of } \\
\text { bolts per row }\end{array}$ \\
$\mathrm{RMR}_{\mathrm{B}}$ & 43 & $5.50 \mathrm{~m}$ & $1.60 \mathrm{~m}$ & $0.90 \mathrm{~m}$ & 6 \\
$\mathrm{RMR}_{\text {retro }}$ & 68 & $5.50 \mathrm{~m}$ & $1.00 \mathrm{~m}$ & $1.20 \mathrm{~m}$ & 5 \\
\hline
\end{tabular}

Table 8. Roof support design for intersection, considering bolt diameter $16 \mathrm{~mm}(5 / 8 ")$.

\begin{tabular}{cccccc}
\hline RMR scenario & Rating & Diagonal & Bolt len. & $\begin{array}{c}\text { Bolt spacing } \\
(\mathrm{SF}=1.7)\end{array}$ & $\begin{array}{c}\text { Numb. of the } \\
\text { bolts per row }\end{array}$ \\
\hline RMR $_{\mathrm{B}}$ & 43 & $7.89 \mathrm{~m}$ & $2.20 \mathrm{~m}$ & $0.70 \mathrm{~m}$ & 11 \\
$\mathrm{RMR}_{\text {retromed. }}$ & 68 & $7.89 \mathrm{~m}$ & $1.30 \mathrm{~m}$ & $1.00 \mathrm{~m}$ & 8 \\
\hline
\end{tabular}


Table 9 shows the results based on the ARBS method [10]. The method suggested for bolt length and support intensity. The PRSUP $_{G}$ intensity $=7.4 \mathrm{t} / \mathrm{m}$ with bolt length of $1.3 \mathrm{~m}$ for the Is $=7.89 \mathrm{~m}$ and entry width of $5.50 \mathrm{~m}$. These results were obtained in a similar way to the step-by-step sizing guide presented in [10].

Considering the values of support intensity suggested in Table 10, different configurations of number and spacing between bolts $\left(N_{b}\right.$ and $\left.S_{b}\right)$ were simulated, with length $\left(L_{b}\right)$ fixed in 1.4 meters, which provided the individual capacity $(C)$ of the support device to be applied. The results of the design are presenting below in Table 10.

From the simulations presented in Table 10, it could be observed that the spacing of $1.0 \mathrm{~m}$ between bolts is similar to the traditionally applied in the mine (Table 1). If dimension of $5.50 \mathrm{~m}$ is taken into account, the ARBS methodology pointed out as effective the intensity of support for a configuration similar to that mentioned, however, with only 4 bolts per line.

The support design methods developed by [2] [6] [10] [11], and proposals in the present study met the geological/geotechnical roof scenario were created exclusively for the selection of a support system, in which the bolt must be fully grouted bolt. In this case, the function of the bolts is to increase the support capacity of the immediate roof and create a beam to support rock load above the beam and the beam itself. Therefore, the change for the original support design is to modify the bolt system from point anchored bolt to fully grouted bolt. Figure 9 shows both systems for the two scenarios of roof layers thickness.

Again, the author messed up comma and dot for the numbers in Figure 9.
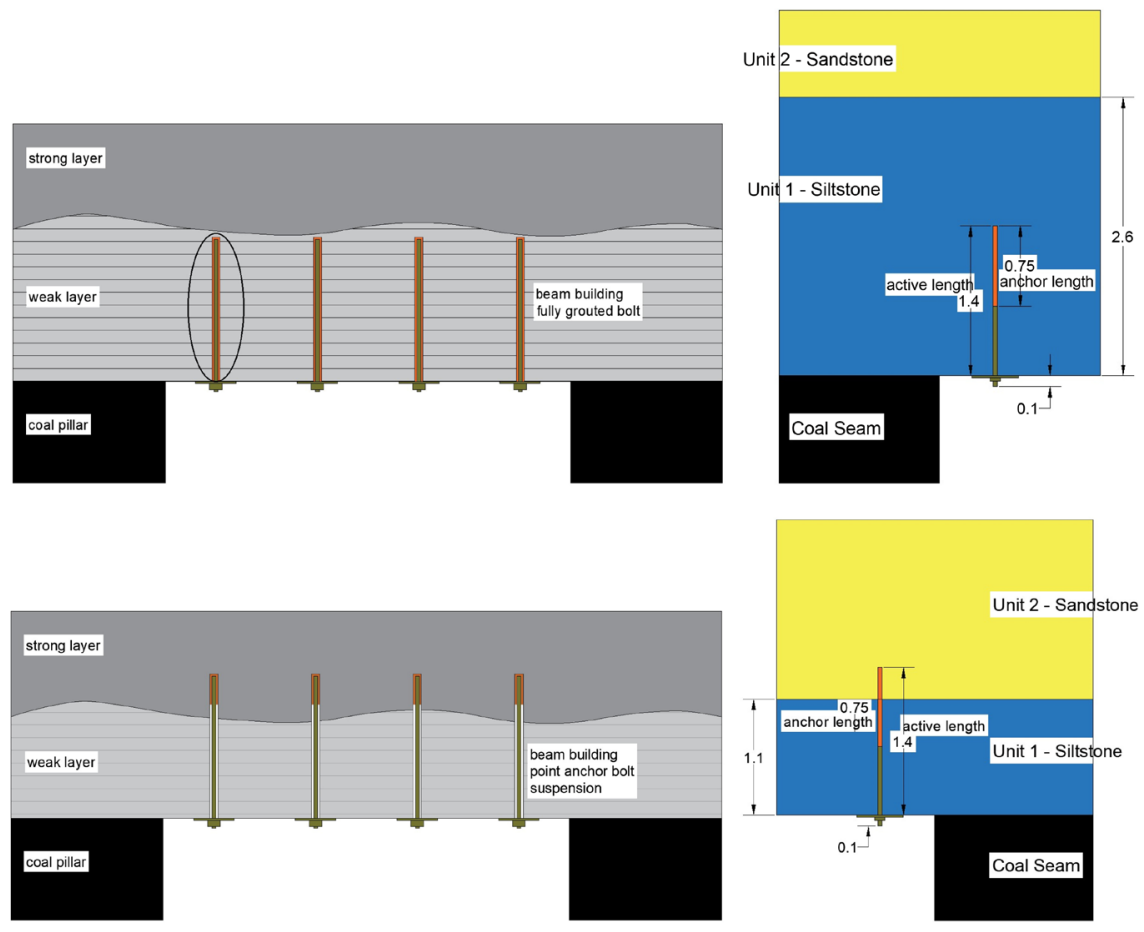

Figure 9. Roof support design for the two scenarios for immediate roof layer (siltstone). 
Table 9. ARBS support design for CMRR 42.3.

\begin{tabular}{lccccc}
\hline \multicolumn{5}{c}{ Roof support design-ARBS methodology } \\
\hline Intersection (Is) & Entry $\left(\mathrm{W}_{\mathrm{e}}\right)$ & $\begin{array}{c}\text { CMRR hole } \\
(\mathrm{FT}-02)\end{array}$ & $\begin{array}{c}\text { Suggest } \\
\text { Inters. } \\
\text { Span }\left(\mathrm{Is}_{\mathrm{G}}\right)\end{array}$ & $\begin{array}{c}\text { Bolt len. } \\
\left(\mathrm{L}_{\mathrm{b}}\right)\end{array}$ & $\begin{array}{c}\text { Required Roof Bolt } \\
\text { Intensity }\left(\text { PRSUP }_{\mathrm{G}}\right) \\
(\mathrm{SF}=1.2)\end{array}$ \\
\hline $\mathrm{MIN}=7.89 \mathrm{~m}$ & $\mathrm{MIN}=5.50 \mathrm{~m}$ & 42.3 & $9.45 \mathrm{~m}$ & $1.3 \mathrm{~m}$ & $\begin{array}{c}7.4 \mathrm{t} / \mathrm{m} \\
(5.0 \mathrm{Klb} / \mathrm{ft})\end{array}$ \\
\hline
\end{tabular}

Table 10. Simulation of bolt design for different bolt spacing.

\begin{tabular}{|c|c|c|}
\hline \multicolumn{3}{|c|}{$\begin{array}{l}\text { Suggest capacity per Bolt- } S_{b}=1.0 \mathrm{~m} \\
\text { PRSUP }_{G}=7.4 \mathrm{t} / \mathrm{m}(5.0 \mathrm{Klb} / \mathrm{ft})\end{array}$} \\
\hline $\mathrm{S}_{\mathrm{b}}=1.0 \mathrm{~m}$ & & $\mathrm{~S}_{\mathrm{b}}=1.0 \mathrm{~m}$ \\
\hline $\mathrm{W}_{\mathrm{e}}=5.50 \mathrm{~m}$ & & $\mathrm{~W}_{\mathrm{e}}=5.50 \mathrm{~m}$ \\
\hline $\mathrm{L}_{\mathrm{b}}=1.4 \mathrm{~m}$ & & $\mathrm{~L}_{\mathrm{b}}=1.4 \mathrm{~m}$ \\
\hline $\mathrm{N}_{\mathrm{b}}=4$ & & $\mathrm{~N}_{\mathrm{b}}=5$ \\
\hline$C=7.3 \mathrm{t}$ & & $C=5.8 \mathrm{t}$ \\
\hline \multicolumn{3}{|c|}{$\begin{array}{l}\text { Suggest capacity per Bolt }-\mathrm{S}_{\mathrm{b}}=1.30 \mathrm{~m} \\
\text { PRSUP }_{\mathrm{G}}=7.4 \mathrm{t} / \mathrm{m}(5.0 \mathrm{Klb} / \mathrm{ft})\end{array}$} \\
\hline \multicolumn{3}{|c|}{$\mathrm{S}_{\mathrm{b}}=1.30 \mathrm{~m}$} \\
\hline \multicolumn{3}{|c|}{$\mathrm{W}_{\mathrm{e}}=5.50 \mathrm{~m}$} \\
\hline \multicolumn{3}{|c|}{$\mathrm{Lb}_{\mathrm{b}}=1.4 \mathrm{~m}$} \\
\hline \multicolumn{3}{|c|}{$\mathrm{N}_{\mathrm{b}}=4$} \\
\hline \multicolumn{3}{|c|}{$C=9.5 \mathrm{t}$} \\
\hline \multicolumn{3}{|c|}{$\begin{array}{l}\text { Suggest capacity per Bolt }-\mathrm{S}_{\mathrm{b}}=1.40 \mathrm{~m} \\
\quad \operatorname{PRSUP}_{\mathrm{G}}=7.4 \mathrm{t} / \mathrm{m}(5.0 \mathrm{Klb} / \mathrm{ft})\end{array}$} \\
\hline \multicolumn{3}{|c|}{$\mathrm{S}_{\mathrm{b}}=1.40 \mathrm{~m}$} \\
\hline \multicolumn{3}{|c|}{$\mathrm{W}_{\mathrm{e}}=5.50 \mathrm{~m}$} \\
\hline \multicolumn{3}{|c|}{$\mathrm{L}_{\mathrm{b}}=1.4 \mathrm{~m}$} \\
\hline \multicolumn{3}{|c|}{$\mathrm{N}_{\mathrm{b}}=4$} \\
\hline \multicolumn{3}{|c|}{$\mathrm{C}=10.2 \mathrm{t}$} \\
\hline
\end{tabular}

\section{Conclusions}

In all 11 practical cases evaluated, the rupture height was identified as conditioned to oscillations in the thickness of the siltstone. The increase of the thickness of the siltstone, and consequent elevation of contact with the sandstone layer resulted in the loss of the function performed by the standard support design applied in the whole mine.

The results obtained from the analysis of the underground support system, considering the RMR index from the geomechanics characterization description from drill core were more conservative when compared to those achieved through the methodology (ARBS/CMRR).

With reference to the cases of failure at the intersections, the ARBS-Analysis 
of Roof Bolt Stability [9] support design method indicated as adequate the support standard configuration employed in the mine. In case of higher siltstone thickness, the system must change to a fully grouted roof bolt.

\section{Conflicts of Interest}

The authors declare no conflicts of interest regarding the publication of this paper.

\section{References}

[1] Torres, G.A. (2018) Análise de rupturas do teto imediato em mina de carvão, camada Barro Branco. Dissertação para obtenção do título de Mestre em Engenharia, Universidade Federal do Rio Grande do Sul, Porto Alegre, 112 p.

[2] Unal, E. (1986) Empirical Approach to Calculate Rock Loads in Coal Mine Roadways. 5th Conference Ground Control Coal Mines, West Virginia University, Morgantown, 11-13 June 1986.

[3] Bieniawski, Z.T. (1989) Engineering Rock Mass Classifications. John Wiley \& Sons, Hoboken, $251 \mathrm{p}$.

[4] Mark, C.E. and Molinda, G.M. (1996) Rating Coal Mine Roof Strength from Exploratory Drill Core. In: Peng, S.S., Ed., Proceedings of the 15th International Conference on Ground Control in Mining, Colorado School of Mines, Golden, 415-428.

[5] Zingano, A.C., Koppe, J.C., Costa, J.F., Felipe, C.L.J. and Peng, S. (2008) In-Situ Tests and Numerical Simulation about the Effect of Annulus Thickness on the Resin Mixture for Fully Grouted Resin Bolt. Effect. Proceedings of the 27 th International Conference on Ground Control Morgantown, Morgantown, June 2008, 284-290.

[6] Laubscher, D.H. (1977) Geomechanics Classification of Jointed Rock Masses-Mining Applications. Transactions of the Institutions of Mining and Metallurgy, 86, A1-A8.

[7] Mark, C. (2000) Design of Roof Bolt Systems: New Technology for Coal Mine Roof Support. U.S. Department of Health and Human Services, Public Health Service, Centers for Disease Control and Prevention, National Institute for Occupational Safety and Health, DHHS (NIOSH) Publication, Pittsburgh.

[8] Molinda, G.M. and Mark, C. (1993) The Coal Mine Roof Rating: A Practical Rock Mass Classification for Coal Mines. In: Peng, S., Ed., Proceedings 12 th Conference on Ground Control in Mining, West Virginia University, Morgantown, 92-103

[9] Peng, S.S. (2008) Coal Mine Ground Control. John Wiley \& Sons, Hoboken, 600 p.

[10] Mark, C. and Molinda, G.M. (2003) The Coal Mine Roof Rating in Mining Engineering Practice. In: Aziz, N., Kininmonth, B., Eds., Proceedings of the 4th Underground Coal Operators' Conference, Australian Institute of Mining and Metallurgy, Carlton.

[11] Unal, E. (1983) Design Guidelines and Roof Control Standards for Coal Mine Roofs. PhD Thesis, Pennsylvania State University, State College, 355 p. 